\title{
Microfinance Accountability in Cameroon; A cure or a Curse for poverty alleviation?
}

\section{Introduction}

In this paper, we augment the debate about accountability within Microfinance Institutions (MFIs) by arguing that managers and accountants of MFIs should work in consultation with all stakeholders and seek their involvement in any decision making processes that will impact on their lives and roles. We take this position especially as accountability is an elusive concept packed with abstract meaning and therefore resulting to different meanings and definitions (Sinclair, 1995, Demirag et al., 2004). In our case, we look at the definition and meaning of accountability from the communal (Demirag et al., 2004) perspective since MFIs main role in the fight against global poverty is to raise incomes of the poor and broaden financial markets for the poor through provision of credit to small scale entrepreneurs who have been deprived of credit in major financial or capital markets (Armendáriz de Aghion and Morduch, 2000). In this paper, we adopt the definition of accountability as put forth by Demirag et al., (2004: 64), as "the management of expectations of various stakeholders, often with diverse and conflicting objectives". So as to broaden this debate on MFIs accountability, through this paper, we identify the different forms of accountability practices existing in Cameroon MFIs, explore how such practices have evolved and become institutionalised through time and show the effects of these accountability practices on poverty alleviation.

Unfortunately, due to pressure from donors, a majority of MFIs are unable to get other stakeholders involved in the decision making processes. Pressures from donors have pushed these MFIs to employ unorthodox accountability practices to meet up their objectives and costs (Armendariz de Aghion and Morduch, (2000) and Dixon et al, (2006). Unerman and O'Dwyer (2006b) argue that, as a result of donor pressure on MFIs, two types of unorthodox accountability practices, Functional and Social accountabilities, have emerged as a principal way for MFIs to curtail such pressures.

Inspired by these findings, this study is based on empirical studies to understand the impact of using different MFI accountability practices in African context, with the particular emphasis on Cameroon. Cameroon as a case study is peculiar in the sense that the rate of poverty in Cameroon is alarming, with more than $40 \%$ (some institutions put the figure at more than $50 \%$ ) of the population below the poverty line. 
Moreover, the Cameroon is ranked by the United Nations Development Programme (UNDP) as 131 out of 177 countries in its index ranking for the poorest countries (UNDP, 2011). The paradox with these poverty figures is that there are more than 120 nongovernmental organisations (NGOs) and 800 MFIs/credit unions handling over FCFA 200 billion (USD 395.4 million) ${ }^{1}$. At the same time, these MFIs constitute the largest in the Central African sub region (CEMAC (Centre Monitaire d'Afrique Centrale) $)^{2}$ with deposits well above $68 \%$ of the regions total and loan portfolio of more than $78 \%$ of the regions gross total (Elle, 2012). Membership (directly and indirectly) of these MFIs counts almost half of the country's population.

This study is based on the in-depth interviews conducted in Cameroon in two phases: first, between the period May to June of 2011 and second., between July to August 2012 with managers and accountants of MFIs of the two largest MFI networks in Cameroon (CamCCUL and $\mathrm{MC}^{2}$ Networks), regulatory authorities in the Ministry of Finance, Professional Consultants and MFI clients and non clients. The study adopts the new institutional theory of DiMaggio and Powell (1983) as its theoretical framework to analyse how these accountability practices evolved and are institutionalised within the MFI sector in Cameroon.

This paper is structured as follows; next two sections look at the microfinance, accounting and accountability research in emerging economies and state of the microfinance industry as it is today around the world and Cameroon, in the fourth section we present our methodology for this research and theoretical framework to show how these accountability mechanisms are institutionalised in Cameroon MFIs and discuss the findings of these institutionalised accountability mechanisms practiced by MFIs in Cameroon; and in the fifth section, we draw our conclusions as to whether these institutionalised accountability mechanisms practiced by MFIs in Cameroon are a cure or a curse for poverty alleviation.

\footnotetext{
${ }^{1}$ The Exchange rate FCFA to USD as of the day of this paper stands at 1USD equals 505.8 FCFA

${ }^{2}$ CEMAC countries are: Cameroon, Chad, Central African Republic, Equatorial Guinea, Gabon and the Republic of Congo
} 


\section{The state of the microfinance industry}

According to the State of the Microcredit Summit Campaign 2011 Report, 641.1 million of the world's poorest people now have access to financial services through MFIs, banks, NGOs, and other nonbank financial institutions. Out of the 641.1 million world's poorest people that received loans from over 3,589 microcredit institutions between 1997 and 2009, 128.2 million were the poorest of the poor who received their first ever loan (Daley-Harris, 2011). This has resulted in a drop in the number of people living in extreme poverty (less than \$1.25 per day) from 137 million in 2011 to 124 million in 2013 (MSC, 2013)

Unfortunately, microfinance is evolving during an era of trade liberalisation, Structural Adjustment Programmes (SAP) and the reinforced belief in the virtues of the markets. This was preceded by years of heavily subsidised industries and generally ineffective government and donor financed credits programmes that have failed to benefit the poor to any significant extent and therefore destroying many of the financial institutions that are suppose to carter for their needs and their natural credit culture (Harper, 2003). This has made microfinance unable to sufficiently penetrate the poorer strata of the poor while excluding some of the poor (Morduch and Haley, 2001). Those excluded from the benefits of microfinance are the poor with little or no entrepreneurial skills, the mentally ill and sick group, the destitute and those below the poverty line.

In order to stabilise these imbalances that have destroyed many of the MFIs and the natural credit culture of the poor and left these poor without any significant benefits, Harper (2003) states that, microfinance advocates have put forward a win-win proposition that leading MFIs with good banking policies at the end of the day will obviously be those considered to have alleviated the most poverty (Morduch, 2000). Unfortunately, this proposition has instead divided the microfinance industry into two camps (the welfarist and the institutionist) as to find who can provide the widest platform for financial access to help in poverty alleviation (Woller et al., 1999). This has led to a situation that Morduch (2000) refers to it as a "schism" and has created a rift between the two camps thus making communication difficult. Even if this debate was to be resolved, it has had excruciating implications on the future of microfinance, its guiding principles, its objectives, its clients and its impact on the poor and poverty alleviation (Woller et al., 1999). 
Insert Figure 1 here

\section{Accountability research in emerging economies}

In our contemporary societies, the meaning of accountability is an issue of intense debate and has led to a situation whereby the definition has become a subject of different interpretations in organisations and different people. This has led to the term accountability having different meanings in different political, social, cultural and linguistic settings (Lister, 2003). People working in the sphere of organisational transparency, responsiveness, ethics, legitimacy and regulation, in governments, corporations, or NGOs have often associated different meanings to the word. The reason being, accountability comprises aspects of that willingness to account for ones actions within the society and the obligation to be held accountable for those actions (Lister, 2003).

However, western nations and donor organisations have realised that for long, they condoned with the malpractices in terms of accountability practices within most emerging economies. This is contributing in pushing their citizens further down the poverty line (Yunus, 2003). This has resulted in donor organisations using NGOs to fund MFIs involved with development and poverty alleviation (Unerman and O'Dwyer, 2006a) while trying to institute the notion of accountability. Unfortunately, what these donor organisations do not realise is that there are less stringent accountability practices between the NGOs and the other stakeholders (Dixon et al., 2006). With less stringent accountability requirements for NGOs operating in these emerging economies, the powerful NGOs use their political/economic powers to avoid accountability requirements. To Unerman and O'Dwyer (2006a), the accountability relations within NGOs and its stakeholders is often limited to upward accountability mechanisms to funders by the beneficiaries rather than being communal in nature (Demirag et al., 2004).

Our argument is that donor organisations and agencies have influenced accountability practices within the microfinance sector and emerging economies either positively or negatively. According to Riddell (1992: 53), the World Bank and the International Monetary Fund (IMF) in an attempt to adjust the malfunctioning economies of emerging economies through "currency devaluation, the removal/reduction of the state from the workings of the economy, the elimination of subsidies in an attempt to reduce expenditures, and trade liberalisation" instituted SAP that has had an impact on both the 
economies and geo-politics of these states by increasing the divide between the urban and the peasant populations and increased levels of unemployment. To Edwards and Hulme (1996), the decision by most multilateral and bilateral agencies in a bit to promote the New Policy Agenda through NGOs with the aim of promoting good governance and ensure accountability has often led to distorted accountability and weakened systems of legitimacy. This has led to NGOs and donors focusing "on short-term "functional", accountability responses at the expense of longer-term "strategic" processes necessary for lasting social and political change" (Ebrahim, 2003: 813).

\section{Theoretical Framework}

The theoretical framework for this paper is the new institutional theory by DiMaggio and Powell (1983). Our choice of institutional theory as our theoretical framework for this study is based on the fact that, institutional theory as a theoretical framework for organisational analysis of a case study places more emphasis on adaptive change and provides "a means of instilling value, supplying intrinsic worth to a structure or process that, before institutionalisation, had only instrumental utility" (Scott, 1987: 496).

Institutional theorists argue that, in organisations, things are done in a certain manner simply because it has become the only way to do them. This pattern of doing things has evolved over time and become legitimised within organisations and environments (Eisenhardt, 1988). To Scott (2001), institutionalisation does not only come through legitimisation, but through deinstitutionalisation of existing norms and practices in which institutions become weakened and disappear so as to accommodate new changes. The process of deinstitutionalisation occurs as a result of three major sources of institutional norms and practices; functional, political and social sources (Oliver, 1997). To DiMaggio and Powell (1983), isomorphism has become the norm of most organisations especially as at the beginning, organisations seem variable and as time goes on, they tend to become homogenous in nature and strive at achieving homogeneity rather than efficiency. This has led to most organisations adopting reforms as a symbol of legitimatisation rather than for efficiency (Tolbert and Zucker, 1983).

In this study, our use of institutional theory is mostly concerned with understanding the institutional pressures and changes (isomorphisms) that MFIs in Cameroon have undergone in order to accommodate the changes in accounting and accountability practices. Our use of institutional theory in this case is to explain how 
change can be diffused within an organisation and a sector (Bell et al., 2012). We are using the Microfinance sector in Cameroon to explain how conflicting institutional pressures resulting from differences of accountability practices can be resolved and also expose the unintended consequences of both resistance and passive actions of local actors (Bell et al., 2012). In order to help the reader understand how these three phases of isomorphism (coercive, mimetic and normative) occur within any organisation and how this might affect the accountability practices in place, Mizruchi and Fein (1999: 657), argue that there is no clear distinction empirically on how each of these three phases of isomorphism occurs but rather that "each involves a separate process, but two or more could operate simultaneously and their effects will not always be clearly identifiable".

Coercive isomorphism concerns the methods through which organisations are pressurised by external organisations on which they depend to conform to certain norms so as to meet certain cultural and organisational expectations (Rodrigues and Craig, 2007).

Mimetic isomorphism refers to the manner in which organisation as a result of the pressures from external sponsors are made to resemble other institutions within the industry that have been seen as successful (Rodrigues and Craig, 2007). In the case of the microfinance industry, since the early days of Jonathan Swift, the industry has undergone a series of changes and seen the introduction of new services all with the aim of offering a wider platform to reach the poorest of the active poor (Daley-Harris, 2002).

Normative isomorphism refers to when people working within the organisations with similar interest organise themselves into a professional base with the aim of "promoting their cognitive base, diffuse shared orientations and organisational practices, and legitimize their activities" (DiMaggio and Powell, 1983: 152 - 153). Rodrigues and Craig (2007) argue that, within organisations, there are two methods through which people act in order to legitimise their activities; these are through networks through which these social actors created in their formal education or through an elaborate professional network that spans across the organisation and thus facilitate these social actors to rapidly diffuse their actions and practices across the entire organisation. Through such professional networks, these actors are able to exert their control of the organisation by controlling the registration and certification procedure within the organisation and promulgate normative and mandatory rules that all other members are compelled to follow (Rodrigues and Craig, 2007). 


\section{Research Method}

The main research method for this study is case study based on 35 in-depth interviews (10 MFI managers and accountants, 10 MFI clients and 10 MFI non clients, 3 government officials and 2 accounting professional) conducted in Cameroon with managers and accountants of MFIs of the two biggest MFI networks in Cameroon (CamCCUL (Cameroon Cooperative Credit Union League) and $\mathrm{MC}^{2}$ (Mutuelle du Croissance Communautaire)), regulatory authorities in the Ministry of Finance, Professional Consultants and MFI clients and non clients. In addition, secondary data was gathered from official documents published by government, MFI and professional accounting bodies. 35 respondents were chosen from 70 who agreed to participate in the research. The 35 respondents selected were based on the criteria that they must have been working within the MFIs for at least 5 years. The same questions were asked to all respondents. The interviewer role was controlling the discussions while allowing the respondents to answer the questions as much as possible. The interviews lasted between 45 minutes to 2 hours. The topics discussed during the interview process are included in the field work and research design of the study presented in Table 1. Data was analysed using content analysis. Through content analysis, we placed quotes from interviews under themes of our theoretical framework.

\section{Insert Table 1 here}

\section{Microfinance context in Cameroon: the MFI industry, regulations and harmonised accounting system}

Microfinance or the credit union or microfinance idea started in Cameroon in September 1963 when Rev. Father Anthony Jansen, a Roman Catholic priest from Holland introduced the idea in Njinikom, the North West Region (formerly known as North West Province) of Cameroon with the establishment of the St. Anthony Discussion Group. This group was created because the Rev. Father discovered that there was some sort of thrift and loan society ("njangies") existing within the group members, charging high interest rate, in addition to numerous financial problems experienced by the group members. He further realised that most of the farmers were selling their cash crops such as coffee, tea, palm oil and cocoa to money lenders before the harvesting season at very low prices. It is from there 
that the Rev. Father formed the group and explained to them the need for a savings and solidarity group to help one another. As a result of his efforts, sixteen members of this discussion group started with some small contributions that amounted to FCFA 2,100 (\$ 4.2). From this humble idea, the concept of formation of credit unions spread to other parts of the North West, South West Regions and today, the entire Cameroon (Long, 2009).

However, microfinance only gained prominence in Cameroon in the late 1980s, following a banking crisis that saw major commercial banks become bankrupt. At the root of this crisis was multifaceted government intervention, inadequate management, and a virtual lack of enforcement of banking regulations (London, 1989). Before the crisis, commercial banks and specialised institutions financed mainly large public enterprises, cooperatives, and authorised exporters. The rural farmers benefited only from a trickle down effect therefore making lending a monopoly for the rich (Yunus, 2003). These unfavourable conditions obliged the poor to resort to decentralised financial institutions and informal financial markets, in this case Credit Unions, microcredit institutions, and MFIs.

The microfinance industry has since been on the rise in Cameroon and CEMAC. Cameroon's MFIs constitute the largest in the area with deposits of more than $68 \%$ of the area total and loan portfolio of more than $78 \%$ of the area gross total (Elle, 2012). However, as a result of errors from these MFIs, the late 1990s witnessed the biggest losses incurred by the MFIs in Cameroon. This led to MFIs experiencing high arrears in loan repayment and debts which amounted to about a quarter of the overall total loan portfolio and losses registered in the sector (Coulter and Abena, 2010, Elle, 2012). As a result, a series of legislations have been passed regulating the sector with the aim of putting in place a system of good governance and accountability aimed at protecting the deposits of the poor.

\section{Microfinance regulations in Cameroon}

Firstly, the OHADA (l'Organisation pour l'Harmonisation en Afrique du Driots des Affaires) Legislation on cooperative societies operating in Africa came at the time when there were calls for harmonisation of business laws in Africa. The OHADA treaty on cooperative societies is a treaty intended to bind all member states who are signatory to the OHADA treaty of 1993 (OHADA, 2011). However, with Africa consisting of different sub regions, the monetary authority of each sub region is required to come up 
with regulations for their various cooperatives and MFIs, but such laws have to be in line with the general principles of the OHADA law on cooperative societies (OHADA, 2011).

This treaty is divided into four main parts (general guidance on formation of Cooperative Societies in Africa, guidance as to what should be done in case of dissolution of any cooperative society, penalties and sanctions, and other issues relating to the activities of Cooperative Societies in Africa), and into 390 Articles (OHADA, 2011). In the case of CEMAC sub region, the treaty came when there was already a regulation; COBAC (Commission Bancaire de l'Afrique Centrale) regulations on cooperative societies adopted and implemented in 2002 (COBAC, 2002).

COBAC has as mission, the regulation of banking activities in CEMAC but was called in to regulate the Microfinance sector following the huge losses of the 1990s. As a result of the convention of 17 January 1992, COBAC instituted the regulation governing the exercise and control of MFI activities in the CEMAC sub region (COBAC, 2002). In doing so, COBAC modelled some of its articles on the French law on associations of 1930 and the Cameroon law on associations of 1990 (Bocqueraz, 2001).

COBAC regulations came at a time when most MFIs operating in the sub region had believed to have reached financial sustainability and were trying to operate as commercial banks or financial institutions (Tucker and Miles, 2004). This resulted in competition between MFIs thus affecting lenders and decreased accountability (McIntosh et al., 2005). As McIntosh et al (2005) argue, with the increase number of MFIs operating in the sub region, MFIs were competing among themselves and were unable to price the risk associated with the uncollateralised loans given these poor clients. Some of these poor took advantage of the situation and took out multiple loans from different MFIs and were unable to repay This resulted in high debts and the high delinquency of the 1990s (Dixon et al., 2007). In order to recover these debts, MFIs were forced to employ various unorthodox methods (Dixon et al., 2007). So as to control the systematic abuse of lenders and protect the interest of the poor, COBAC regulations; firstly forbid MFIs using the appellation of "bank" or "Financial Institution" and require that their denominations be followed by the appellation "Microfinance Institutions" (COBAC, 2002, Article 6). Secondly, MFIs are grouped into three different categories (category one, category two, and category three), which each of these categories having a fixed minimum capital requirement and type of transaction they are required to offer their clients (COBAC, 2002, Articles 5, $7 \&$ 9). Category one MFIs refer to MFIs that collect their member savings and use these savings to 
grant loans exclusively to these members and there are no minimum capital requirements for this category. Category two MFIs refer to MFIs that carry out savings collection activities and can grant loans to both the said members and third parties. The minimum capital requirement for this category was fixed at FCFA50 million $(\$ 99,000)$. However, new government legislation in 2012 increased this minimum capital requirement to FCFA2 billion ( $\$ 4$ million). Category three MFIs refer to those institutions that have the ability to grant loans to third parties without necessarily carrying out any prior saving collections. The minimum capital requirement for this category was fixed at FCFA25 million $(\$ 49,500)$. Again, the new government legislation increased this minimum capital requirement to FCFA100 million $(\$ 198,000)$.

Other important aspects of the COBAC regulations includes differentiating between MFIs that do operate as independent MFIs and those that decide to exercise their activities under an umbrella organisation, such as the CamCCUL and MC ${ }^{2}$ networks (COBAC, 2002, Article $12 \&$ 13). If MFIs decide to operate under an umbrella organisation, articles 15 clearly spells out the prerogatives of the umbrella organisation and affiliates, such as how to protect the network financial liquidity, what happens to the financial stability of the network should one or more affiliates become bankrupt, conditions of internal control of the network, the definition of which accounting plan, norms and procedures to follow, how accounting documents can be consolidated following the stated procedures laid down by the banking commission.

The intention of these regulations is to provide a wider platform for these MFIs to reach the poor, especially the category one MFIs. Today, the category one MFIs control more than 80 percent of the microfinance market in Cameroon and handles more than 75 percent of deposits and savings from the poor (this information was gathered through document review during the fieldwork).

\section{Influence of external pressures to harmonise accounting practices in Cameroon}

The OHADA treaty of 1993, on which the 2011 OHADA law on Cooperative Societies has been developed is the result of the harmonisation for business laws that came at a back drop of the New Partnership for African Development (NEPAD) agreement of June 2002 at the G8 Kananaskis summit. According to Enonchong (2007: 95) the principal objective of the OHADA treaty is "to harmonise and modernise business laws in Africa so as to facilitate commercial activity, attract foreign investment and secure economic 
integration in Africa" as stipulated "within the objectives of the NEPAD agreement". This in effect has resulted in the drafting of OHADA treaty that has been extended into the microfinance sector.

These changes in accounting standards have an effect on accountability in Cameroon especially as the 2 Cameroons have different accounting histories. The French and British Cameroon both have different political and accounting histories. Prior to the period up to unification in 1961, the British Cameroonians were used to Chapter 37 of the Laws of the Federation of Nigeria and Lagos, 1958, which was modelled on the British Companies Ordinance of 1922, while the French Cameroon were using Ordonnance de Commerce of 1673 which was put through by Jean-Baptiste Colbert during the reign of Louis XIV, and the Napoleonic Commercial Code of 1807, that influenced the bookkeeping provisions of commercial law throughout Continental Europe (except the United Kingdom), Francophone Africa, and beyond (Elad and Tumnde, 2007). Chapter 37 of the Laws of the Federation of Nigeria and Lagos, 1958, had no provision or requirement for organisations operating in British Cameroon to keep any records of accounting and bookkeeping (Elad and Tumnde, 2007). After unification on February 1961, even with both French and British Cameroon as one nation, these accounting systems were still maintained, even though with slight modifications for French Cameroon with the introduction of the Plan Comptable General (PCG) (Barrett and Roy, 1976).

Because of pressure from international donors, in order to qualify for aid, African countries hastily drafted and adopted OHADA treaty in 1993 (London, 1989, Elad and Tumnde, 2007, Enonchong, 2007). Basically, OHADA treaty is a blend of the AngloSaxon model of Accounting with the French accounting system approach by codifying some of the provisions of International Financial Reporting Standards (IFRS) and incorporating them as articles within the framework of OHADA in line with the French civil law tradition "wherein codes and statutes are highly structured and systematized" (Elad and Tumnde, 2007: 1). The OHADA treaty is currently ratified by 17 African countries: 14 of which are Francophone African states, one Spanish-speaking country (Equatorial Guinea), one Portuguese-speaking country (Guinea Bissau), and one bilingual country (Cameroon) that has both French and English as official languages.

Unfortunately, the OHADA treaty replaces the OCAM (Organisation Commune Africaine et Malgache) accounting plan which was introduced in Cameroon in 1963. The OCAM Plan according to Elad (1992: 87) "was very much in tune with the spirit 
of the British Corporate Report (ASC, 1975), the Canadian Stamp Report (CICA, 1980) and the Trueblood Report (AICPA, 1973)".

\section{Discussion and analysis}

\section{Impact of accounting harmonisation and MFI regulations on microfinance practices in}

\section{Cameroon}

The pressures to harmonise accounting practices in Cameroon had a direct impact on MFIs. As DiMaggio and Powell (1983) argue, a powerful institution through coercive isomorphism forces organisations to change their practices so as to meet certain cultural and environmental expectations. In the case of MFIs operating in Cameroon, these pressures as a Director in the Ministry of Finance argue came in the form of;

'NEPAD has four principal objectives; eradicating poverty, empowering women, promoting sustainable growth and development in Africa, and the integration of Africa into the World economy. Today, we are talking about microfinance and at the CEMAC level, we see that microfinance is the spine to achieve these four objectives as these institutions touches on every aspect of the NEPAD agreement"

With MFIs pressurised to meet the demands of the regulators (Flack and Ryan, 2003), another Director in the Ministry of Finance argue that MFIs that comply are rewarded with "a common regulatory regime that is almost same as in their (funders) countries and for which they will be able to carry out any investments without fear.".

What we find here is a situation where MFIs have been forced to change their accounting standards with the aim of meeting external donor demands. This is what Di Maggio and Powell (1983) refer to as coercive isomorphism. These pressures as argued by another Director in the Ministry of Finance provides MFIs operating in Cameroon the platform to legitimise their activities with "a common financial reporting system, following the provisions of IFRS, a common system of presenting balance sheet information etc" that will help MFIs "adequately meet the needs of the poor and be more accountable to their members".

MFIs in Cameroon in order to achieve homogeneity (mimetic isomorphism) (DiMaggio and Powell, 1983) a manager of an MFI argued; 
"These changes in regulations governing the microfinance sector in Cameroon were necessary. This is because, in the past and as a result of the lack of strict control and supervision of the industry, we became very complacent and screening between good and bad customers was less stringent leading to the huge losses that many of the MFIs operating in Cameroon incurred in the late 1990s".

To an accountant of an MFI, this homogeneity can be achieved through having in place "better explanations as to how to assess the risk involved with micro lending, single financial reporting standards across the entire microfinance sector". $\mathrm{He}$ further argued that these regulations will further help MFIs gain legitimacy especially as "there were discrepancies leading to two different accounting plans being used across the MFI sector in Cameroon".

Unfortunately as Flack and Ryan (2003) argue, the consequences often associated with such pressures are increase professionalism and the development of large bureaucratic structures so as to counteract these pressures as we show in the following sections.

\section{The beginning of an impending crisis - dysfunctional accountability}

Understanding the accountability mechanism that existed within the MFI industry in Cameroon for us required tracing back to the system of accountability that was initially in place before the COBAC regulation. Prior to the COBAC regulations, there were discrepancies in accountability practices due to differences in accounting practices between MFIs in the French and English zones of Cameroon. In the French part, MFIs adopted $\mathrm{OCAM}^{3}$ whereas MFIs in the English zone were using British Accounting system.

The reason why MFIs adopted different accounting practices as argued by an elderly MFI client, is because of "the colonial rule of the Germans, French and British administrators that required complete compliance from leaders in these different societies". Following on from these historical roots, a manager argued that "the regulations have created bureaucratic structures that do not take into consideration the environments in which the MFIs operate". He further argued that "the regulations have created conflict of interest between managers, clients and shareholders and disrupted governance within these

\footnotetext{
${ }^{3}$ Discussion about OCAM Accounting is beyond the scope of this paper.
} 
MFI". As Bakker et al (2014) argue, these are the unintended consequences of homogeneity. As another MFI manager argued, "the regulations in place do not promote accountability but have left MFIs to focus on meeting the requirements of the regulations rather than being closer to the poor and offer advice as to which service best suit their needs".

Due to prior lack of accountability, strict regulations and control of the microfinance sector, leading MFIs incurred debts of more than a quarter of the overall losses incurred by MFIs in the CEMAC sub region. The reason for these debts is because annual reports of MFIs that should be used to demonstrate accountability, were used for legitimacy rather than efficiency (DiMaggio and Powell, 1983, Flack and Ryan, 2003). In this case, we are left with a situation described by an MFI client as "a breakdown of a whole system caused by people becoming more selfish and less accountable to each other".

However, as Scott (2001) argue, for an organisation to gain legitimacy this has to come through deinstitutionalising existing norms and practices through which some institutions might become weakened and disappear. The process of deinstitutionalisation of existing practices within the microfinance sector in Cameroon have come through a functional process (Oliver, 1997). This functional process as a director in the Ministry of Finance told us involves categorising MFIs into "category one, two and three and setting their limits and boundaries of operations in terms of capital requirements and consolidation of their accounts". The Director further argues that the functional process weakens some institutions through "capital requirements" and the social process involves "requirements for financial report, to ease control of MFIs, protecting the financial stability of the institution, the poor and shareholders"

According to Bell et al (2012), such changes in both functional and social processes have resulted to decoupling from other organisational actors in order to shield their organisations from the influence of external intrusion (Siti-Nabiha and Scapens, 2005). This resistance according to a consultant comes mostly from the managers who try to maintain the status quo by not operating within the strict limits of the category one institutions. The reason behind this according to the Consultant is because;

"The microfinance sector in Cameroon has become a lucrative investment sector and no MFI is ready to strictly operate under the category for which they were registered. The worse is those affiliated to a network, for they have to pay huge sums to the umbrella organisation as consultation fees which 
often leave these MFIs with little to carter for their business if they have to operate under the category for which they were registered"

One of such reasons for resistance according to Yazdifar and Tsamenyi (2005) is not only because of organisational restructuring in order to accommodate the new changes, but because must changes do not take into consideration local factors such as local power, politics and culture. The reason for such resistance according to this MFI Manager;

"We have pressures from governments to strictly apply the OHADA accounting plan, our shareholders want a return on their investments, and COBAC officials want us to comply with their regulations. So what becomes of the MFI if we are to strictly operate as category one?"

The involvement of external institutions in the regulation of the MFIs in Cameroon has resulted to a dysfunctional form of accountability. As Siti-Nabiha and Scapens (2005) and Yazdifar and Tsamenyi (2005) argue, without taking into account the power of those involved within the organisations, this has resulted into resistance that has destabilised the implementation of any changes in accounting rules and routines. The end result is that the COBAC regulations have given powers to the "Reified Might" to use such power over the "Reified Right" ( in this case the poor) (Ebrahim, 2003). Managers now use such power to satisfy the needs of their employers rather than providing services that can benefit the poor.

\section{The reactions from MFI industry: Manipulative accountability?}

The reason why the industry has undergone such reforms according to DiMaggio and Powell (1983) is to permit these institutions to either ceremonially or actually gain legitimacy through mimetic isomorphism. In order to permit the MFIs in Cameroon gain this legitimacy, the industry has undergone functional, political, and social changes (Oliver, 1997). However, what remains to be seen is how these changes have improved accountability and the fight against poverty.

As part of the social process to either ceremonially or actually gain legitimacy, MFIs in Cameroon have organised themselves into two biggest microfinance consortia, the CamCCUL and $\mathrm{MC}^{2}$ networks. As Greenwood et al (2002) argue, these two networks have diffused their ideas through controlling the registration process. To become 
a member, you need to buy shares within that MFI. These shares according to a consultant are;

"A minimum share of FCFA 10,000, solidarity fund which is $10 \%$ of share capital, registration fees of FCFA 2,500, building fund of FCFA 25,000. But what these institutions do is they require customers to buy at least 3 shares that should amount to FCFA 30,000. So if we add up these sums, we see that in order to become a member of an MFI, you need at least FCFA 45,000 (approximately \$88.3), thus putting microfinance above the reach of the ordinary poor who by definition lives on less than $\$ 1$ or $\$ 2$ a day"

By controlling this registration process, these institutions are able to exert their purposive actions that create, maintain, and potentially disrupt institutions (Yazdifar and Tsamenyi, 2005). This has led to MFIs in Cameroon practising different accountability methods. These two forms of accountability according to a consultant sees "MFIs affiliated to CamCCUL opening offices all the place whereas those affiliated to $\mathrm{MC}^{2}$ are not allowed to do so by their parent company". This has led to a situation which a consultant argues,

"The rural population have become the milking cows of these MFIs who open offices in the rural areas and collect savings from these rural populace and invest in big cities where they are sure to get wealthy individuals so as to make gains from these savings for their shareholders".

As Siti-Nabiha and Scapens (2005) and Yazdifar and Tsamenyi (2005) argue, the actions of these organisational participants have seen them destabilise not only the institutions, but create more wealth for their owners by segregating on the poor when it comes to loan sizes. An accountant within the CamCCUL Network admitted that "when we talk about loans granted to the rural poor, these loans are in volumes, but when we talk about loans granted in value, it is the business people who have an upper edge". They also exert their purposive actions through instituting "collaterals" and third party guarantors for the poor to secure loans as attested by a manager. This has led to a situation where "during Board meetings, most shareholders are not interested in whatever story you tell them. All they want to hear is how much dividend they are getting by the end of that financial year". To Bakker et al (2014), this is one of the actions of the passive actors leading to different stakeholders posing different challenges in behaviour, values and attitudes (Javidan and Dastmalchian, 1993). With these challenges in behaviour, values and attitudes, a manager working with CamCCUL network argued that this has not only disrupted the governance of 
these MFIs" but left them no choice than "do whatever it takes to meet up with the demands of our shareholders" such as opening "offices in big cities" targeting "business people who are willing to take out huge loans".

While managers and accountants of the CamCCUL Network are faced with challenges, those of the $\mathrm{MC}^{2}$ Network do not. The reason as the Directors in Afriland First Bank that oversees the control of all $\mathrm{MC}^{2} \mathrm{~s}$ in Cameroon argues is that;

" $\mathrm{An} \mathrm{MC}^{2}$ is that it is an institution opened to help people of the locality for which they are registered. Therefore by opening branches outside of their area of registration means they will obviously not be there to take care of the local indigenes that have savings within that $\mathrm{MC}^{2}$ "

This situation to us sounds logical, for the main reason for an MFI is to offer cheap loans to the poor at affordable interest rates. Thus opening branches in cities thus alienates the poor who are based in villages and who are the majority savers within that MFI from benefiting from the services the MFI has to offer them. And as another Director of Afriland First Bank told us,

"The $\mathrm{MC}^{2}$ operates under the vision that, given the means and potential, the people can together take their destiny in their hands and do something with their poverty situation. Therefore, the $\mathrm{MC}^{2}$ is there to provide them that means and potentials for them (rural masses) to now take their destiny into their own hands and fight poverty".

In order to enable the MFIs in Cameroon mime successful institutions within the industry, they have been forced to change their accounting practices from the British Accounting system and Plan Comptable General to OCAM and now OHADA all with the aim of legitimising their activities (Carpenter and Feroz, 2001). As Scott (1987: 498) argues, the reason why organisations change their accounting practices is not just for legitimacy, but because they might be rewarded with "resources and survival capabilities". Unfortunately, such accounting rule changes within the MFI industry in Cameroon has led to different forms of accountability being practised across the industry (Unerman and O'Dwyer, 2006b). This has compromised the very existence of these institutions so much so that, they now behave as investors rather than helping the poor improve on their livelihood (Yunus, 2003). What happens in essence is different and it is hard to find any MFI in 
Cameroon that was registered as a category one microfinance operating within the strict limits of the category one institutions.

As DiMaggio and Powell (1983) argue, in order for managers and accountants to ease the pressure on them, they use their professional judgements to come up with practices that best suit their needs. One of such practices that managers use for their benefits is by requiring MFIs affiliated to their networks to pay huge fees. To a manager they "have to pay at least 50 per cent of what we make as profits per year to our umbrella organisation so as to remain in the business". These fees according to a director at CamCCUL "is for the training we offer the mangers of the MFIs, to secure funding (if at all) from donors for these MFIs, train these MFIs on basic bookkeeping principles, supervision, control, correct their books in case of any control from the Ministry of Finance and COBAC, and charges for using our trade mark".

In our case, we realise that, MFIs managers use their professional judgements to manipulate the accounting and accountability system to their advantage. This is what DiMaggio and Powell (1983)refer to as normative isomorphism. According to Rodrigues and Craig (2007), managers are able to use their influence which they have developed through their social interactions or formal education or through an elaborate professional network to diffuse their actions and practices across an organisation. In our case, these social actors have developed what we term a "manipulative accountability" practice that gives them the opportunity to focus on short-term outputs and efficiency criteria over longrange goals concerning social development. By doing so, they are able to create more wealth for their shareholders. The end result is, these shareholders fight to alleviate poverty among themselves in the very place before thinking of the poor who technically are supposed to be the sole beneficiaries of MFI services.

\section{The end of an affair - dribbling accountability?}

Due to the changes that the accounting system in Cameroon has undergone, thus leading to the harmonisation of accounting practices in Africa and CEMAC sub region, MFIs managers and accountants have used their professional judgements to organise themselves into two networks thereby influencing the ground rules that other institutions that enter the sector or the regulatory authorities have to follow (DiMaggio and 
Powell, 1983). As a result, these two networks control more than 75 per cent of deposits and 80 per cent of the market share in Cameroon ${ }^{4}$.

With these MFIs having complete control of the sector, they are now only concerned with "return on their investment" as stated by a Director in the Ministry of Finance. When MFIs become concerned with their return on investments, Roberts (2013) argue that they trade off the social impact of microfinance for financial performance and thus push the wellbeing of the poor to the back burner. With MFIs now focusing on financial performance, to a consultant, this creates a "conflict of interest between the MFIs managers, accountants and clients" and leave managers in a dilemma. As a manager of an MFI argued, "we are actually caught in a conflict of interest between the regulatory authorities, our shareholders, our jobs and our clients. So at the end of the day, we have to make decisions if we want to survive and remain in business".

With MFIs facing issues with the governance structure within their organisations coupled with the fact that they now focus on financial performance, MFIs in Cameroon are required to pay corporation taxes. When a Director in the Ministry of Finance was asked why MFIs that have as mission social wellbeing of the poor has to pay corporate taxes, the Director argued that, "MFIs in Cameroon are now purely business entities and make profits more than classical banks in the country. So if a classical bank should pay corporate taxes on profits, it is but normal that MFIs pay taxes as well". According to a consultant, the issue of corporate taxes for MFIs comes from the fact that "the poor clients have paid up to 120 per cent interest rate for an overdraft or loan whereas commercial banks charge between 25 and 40 percent on an overdraft". According to Paul (2010), MFIs are suppose to charge higher interest rates than commercial banks because they incur higher operating costs in their activities. Rather than charging higher interest rates because of higher operating costs, a consultant argues that;

"The whole process surrounding MFIs activities in Cameroon and the provisions of OHADA Accounting treaty has only led to a situation where these MFI managers, accountants and shareholders are there only to alleviate poverty amongst themselves first before thinking of the poor they are suppose to help".

\footnotetext{
${ }^{4}$ These statistics are based on information gathered during interviews
} 
This therefore leaves MFIs operating in Cameroon to adopted different accountability mechanisms in order to meet up with the extra cost, thus alienating the poor who are supposed to be the sole beneficiaries of the microfinance services. Managers and accountants now use their professional judgements that they have developed through their social networks or through the professional education to go around the regulations and practice what we term "dribbling accountability". Through this "dribbling accountability" practice, managers and accountants of MFIs sideline the regulations in place and opt for financial performance rather than go for the social wellbeing of the poor.

\section{Summary and conclusion}

The aim of this study was to identify the forms of accountability practices adopted by the MFIs in Cameroon and explore how such practices have evolved and become institutionalised through the time. The main research method used was case study with in-depth interviews with managers and accountants of two of the biggest microfinance networks in Cameroon, MFI clients and non clients, regulatory officials and accounting professionals. After analysing our data by applying the three elements of institutional theory (coercive, mimic and normative isomorphism), we have identified three forms of accountability practices consistent with MFIs operating within the two major networks in Cameroon; dysfunctional, manipulative, and dribbling accountabilities. As we have showed, the pressures for MFIs in Cameroon to be more accountable to their stakeholders has led to serious consequences of increase professionalism and larger bureaucratic structures thus resulting to MFIs practicing the different forms of accountabilities all with the aim of counteracting these pressures.

As we have showed, the process of forcing MFIs in Cameroon to change their accounting and accountability systems has resulted to what we term "dysfunctional accountability" practice. The COBAC regulations have forced MFIs managers and accountants in Cameroon to strive at achieving homogeneity rather than efficiency. In doing so, this has given powers to the Reified Might to use such power over the Reified Right (Ebrahim, 2003) through creating a complex ownership structure in the form of investors. As a result, managers of these institutions with the aim of satisfying the needs of their employers, have instituted a system of oversight control mechanisms (Ahmed et al., 2010) and given them the opportunity to practice whatever system of accountability they deem appropriate to help achieve the goals of satisfying their employers. 
The process of making MFIs in Cameroon mime other successful MFIs in the sector, this has left MFI managers and accountants striving to satisfy their employers by manipulating the accounting system in place through what we term "manipulative accountability" practice. This form of accountability practice give these MFIs powers to focus on short-term outputs and efficiency criteria, which is generating enough dividends for their shareholders, over long-range goals concerning social development and change by concentrating their activities in urban areas with the aim of targeting rich investors so as to make huge profits for their shareholders.

In order to manipulate the accounting system in place, managers and accountants use their professional judgements to practice what we term "dribbling accountability" practice. Through this form of accountability practice, MFI managers and accountants in Cameroon sideline the regulations in place to control licensing processes, create the ground rules that all other MFIs now have to follow, and practice two distinct methods of reaching the poor which gives them the possibility of legitimising their activities. Again since the MFI sector in Cameroon has turned into an lucrative investment sector, these regulations have created a conflict of interests between the MFI managers, accountants and shareholders on the one hand and MFI managers, accountants and clients on the other.

Moreover, the MFI managers and accountants in order to preserve their jobs, strive at satisfying their shareholders, rather than taking interest in the poor. Consequently, MFIs in Cameroon have ceased being agents of change to the societies in which they are considered as agents of social change (Ebrahim, 2005). The end results is, the (dysfunctional, manipulative and dribbling) accountability practices practiced by MFIs in Cameroon is a curse for poverty alleviation since MFIs now use the powers given them as power of empowerment over the poor rather than power of empowerment of the poor (Jayasinghe and Wickramasinghe, 2011). The end result is, these shareholders fight to alleviate poverty among themselves in the very first place before thinking of the poor who technically are suppose to be the sole beneficiaries of MFI services. 


\section{References}

Ahmed, Z., Hopper, T. \& Wickramsinghe, D. (2010) Hegemony, Counter Hegemony and NGO Accountability Change: BRAC in Bangladesh [pdf]

$<$ http://apira2010.econ.usyd.edu.au/conference proceedings/APIRA-2010-239-Ahmed-

Hegemony-counter-hegemony-and-NGO-accountability.pdf.> [Accessed 12 March, 2016]

Armendariz, B. \& Morduch, J. (2000) Microfinance beyond group lending. Economics of Transition, 8(2): 401-420

Bakker, A., Schaveling, J., Nijhof, A \& Kakabadse, N. (2014) Governance and microfinance Institutions. Corporate Governance: The International Journal of Business in Society 14(5): 637-652

Barret, M.E. \& Roy, J.L. (1976) Financial Reporting Practices in France. Financial Analysts Journal 32(1): 39-49

Bell J., Hoque, Z. \& Arroyo, P. (2012) Management accounting change and sustainability: an institutional approach. Journal of Accounting \& Organizational Change 8(3): 286-309

Bocqueraz, C. (2001) The development of professional associations: the experience of French accountants from the 1880s to the 1940s. Accounting History Review 11(1): 7-27

Carpenter, V.L. \& Feroz, E.H. (2001) Institutional theory and accounting rule choice: an analysis of four US state governments' decisions to adopt generally accepted accounting principles. Accunting, Organisations and Society 26(7-8): 565-596

COBAC (Banking Commission for Central African States) (2002) Reglement CEMAC Relatif aux Conditions d'Exercice et de Controle de l'Activitite de la Microfinance. 01/02/CEMAC/UMAC/COBAC, Cameroon: COBAC

Coulter, J. \& Abena, P.E. (2010) Study of Value Chain Finance for Coffee and Cocoa in Cameroon, Yaounde: UNCTAD

Daley-Harris, S. (2002) Pathways out of poverty: Innovations in microfinance for the poorest families, Bloomfield CT: Kumarian Press

Daley-Harris, S. (2011) State of the microcredit summit campaign report 2011, Washington D.C.: Microcredit Summit Campaign (MSC)

Demirag, I., Dubnick, M. \& Khadaroo, M.I. (2004) A framework for examining accountability and value for money in the UK's private finance initiative. Journal of Corporate Citizenship, 2004(15): 63-76

DiMaggio, P.J. \& Powell, W.W. (1983) The iron cage revisited: Institutional isomorphism and collective rationality in organizational fields. American Sociological Review, 48(2): 147-160

Dixon, R., Ritchie, J. \& Siwale, J. (2006) Microfinance: accountability from the grassroots. Accounting, Auditing \& Accountability Journal, 19(3): 405-427

Dixon, R., Ritchie, J. \& Siwale, J. (2007) 'Loan officers and loan "delinquency" in Microfinance: A Zambian case', Accounting Forum, 31(1): 47-71 Center, April 2005

Ebrahim, A. (2003) Accountability in practice: Mechanisms for NGOs. World Development, 31(15): 813-829

Ebrahim, A. (2005) Accountability myopia: Losing sight of organizational learning. Nonprofit and Voluntary Sector Quarterly, 34(1): 56 - 87 
Eisenhardt, K.M. (1988) Agency-and institutional-theory explanations: The case of retail sales compensation. Academy of Management Journal, 31(3): 488-511

Elad, C.M. (1992) Influences on the Harmonisation of Accounting and Disclosure in Cameroon. PhD Thesis, Accounting and Finance, Glasgow University, UK.

Elad, C.M. \& Tumnde, M. (2007) Uniform Act Organizing and Harmonizing Accounting Systems in the Signatory States to the Treaty on the Harmonization of Business Law in Africa with Commentaries. Paris : Centre National de la Recherche Scientifique, CNRS-Juriscope: 1-46.

Elle, S.M. (2012) 'Microfinance and Entrepreneurship in Cameroon', Journal of Asia Entrepreneurship and Sustainability, 8(1): 121-143

Enonchong, N. (2007) 'The Harmonization of Business Law in Africa: Is Article 42 of the OHADA Treaty a Problem?' Journal of African Law, 51(01): 95-116,

Flack, T. \& Ryan, C.M. (2003) Accountability of Australian nonprofit organisations: Reporting dilemmas. Journal of Contemporary Issues in Business and Government, 9(1): 75-88

Fox, J.A. \& Brown, L.D. (1988) The struggle for accountability: The World Bank, NGOs, and grassroots movements, London: The MIT Press

Greenwood, R., Suddaby, R. \& Hinings C.R. (2002) Theorizing change: The role of professional associations in the transformation of institutionalized fields. Academy of Management Journal, 45(1): 58-80

Harper, M. (2003) Microfinance: evolution, achievements and challenges, ITDG Publishing

Javidan, M. \& Dastmalchain, A. 1993. Assessing senior executives: The impact of context on their roles. The Journal of Applied Behavioral Science, 29(3): 328-342

Jayasinghe K. \& Wckramasinghe, D. (2011) Power over empowerment: Encountering development accounting in a Sri Lankan fishing village. Critical Perspectives on Accounting, 22(4): 396-414

Lister, S. (2003) NGO Legitimacy: Technical Issues or Social Constructs? Critique of Anthropology, 23(2): 175 - 192

London, A. (1989) Money, inflation and adjustment policy in Africa: some further evidence. African Development Review, 1(1): 87-111

Long, I. (2009) Perceptions of Microfinance in Cameroon: A Case Study of UNICS, Yaoundé, [Online] Idependent Study Project Collection, Paper 729, $<$ http://digitalcollections.sit.edu/isp_collection/729> [accessed 9 February, 2016]

McIntosh, C., Janvry, A. \& Sadoulet, E. (2005) How Rising Competition Among Microfinance Institutions Affects Incumbent Lenders. The Economic Journal, 115(506): 987-1004

Mizruchi, M. S. \& Fein, L. C. (1999) The social construction of organizational knowledge: study of the uses of coercive, mimetic, and normative isomorphism. Administrative Science Quarterly, 44(4): 653-683

Morduch, J. 2000. The microfinance schism. World Development, 28(4): 617-629

Morduch, J. \& Haley, B. (2001) Analysis of the effects of microfinance on poverty reduction. NYU Wagner Working Paper No. 1014: Issued June 28, 2002

MSC. 2013. Vulnerability: The State of the Microcredit Summit Campaign Report, 2013 
[Online]. Microcredit Summit Campaign.

$<$ http://www.microfinancegateway.org/p/site/m/template.rc/1.1.18121/>

[accessed 15 February, 2016]

OHADA, (2011) Acte Uniforme Relatif Au Droits des Societes Cooperatives. Yaounde: OHADA, pp. 1-96

Oliver, C. (1997) Sustainable competitive advantage: Combining institutional and resourcebased views. Strategic Management Journal, 18(9): 697-713

Paul, M.S. (2010) 'Bridging the Gap to the Microfinance Promise: A Proposal for a Tax-

Exempt Microfinance Hybrid Entity', New York University Journal of

International Law and Politics, 42(4): 1383-2010

Riddle, J.B. (1992) 'Things fall apart again: Structural Adjustment Programmes in SubSaharan Africa', The Journal of Modern African Studies, 30(01): 53-68

Roberts, P. W. (2013) The profit orientation of microfinance institutions and effective interest rates. World Development, 41: 120-131

Rodrigues, L. L. \& Craig, R. (2007) Assessing international accounting harmonization using Hegelian dialectic, isomorphism and Foucault. Critical Perspectives on Accounting, 18(8): 739-757

Scott, W. R. (1987) The Adolescence of Institutional Theory. Administrative Science Quarterly, 32(4): 493-511

Scott, W. R. 2001. Institutions and Organisations, Thousand Oaks, CA, Saga

Sinclair, A. 1995. The chameleon of accountability: Forms and discourses. Accounting, Organizations and Society, 20(2-3): 219-237

Siti-Nabiha, A. \& Scapens, R. W. (2005) Stability and change: An institutionalist study of management accounting change. Accounting, Auditing \& Accountability Journal, 18(1): 44-73

Tolbert, P. S. \& Zucker, L. G. (1983) Institutional sources of change in the formal structure of organizations: The diffusion of civil service reform, 1880-1935. Administrative Science Quarterly, 28(1): 22-39

Tucker, M. and Miles, G. (2004) 'Financial performance of microfinance institutions: a comparison to performance of regional commercial banks by geographic regions', Journal of Microfinance/ESR Review 6(1): 41-54

UNDP. 2011. Human Development Report [pdf]. <http://hdrstats.undp.org/images/explanations/CMR.pdf> [accessed 7 February, 2016]

Unerman, J. and O'Dwyer, B. (2006a) 'On James Bond and the importance of NGO accountability', Accounting, Auditing \& Accountability Journal 19(3): 305-18

Unerman, J. and O'Dwyer, B. (2006b) Theorising accountability for NGO advocacy. Accounting, Auditing \& Accountability Journal, 19(3): 349-376

Woller, G. M., Dunford, C. \& Woodworth, W. (1999). Where to microfinance. International Journal of Economic Development, 1(1): 29-64

Yazdifar, H. \& Tsamenyi, M. (2005) Management accounting change and the changing roles of management accountants: a comparative analysis between dependent and independent organizations. Journal of Accounting \& Organizational Change, 1(2): 180-198

Yunus, M. (2003) 'Expanding microcredit outreach to reach the Millennium Development Goal: some issues for attention', in International Seminar on 'Attacking Poverty with Microcredit', Dhaka, Bangladesh, 8-9 January, 2003 